\title{
Under the Umbrella of Custom: Harmonious Relationship between Christian and Islam in Tiga Beringin Village and Simpang Pergendangan Village, Karo
}

\author{
Junita Setiana Ginting ${ }^{1}$, Edi Sumarno ${ }^{2}$, Nina Karina ${ }^{3}$, Handoko ${ }^{4}$ \\ 1,2,3,4 Universitas Sumatera Utara, Indonesia \\ junitasetiana@yahoo.com
}

\begin{abstract}
Indonesian society is a pluralistic society. The pluralism of society can be seen from the diversity of languages, ethnicities and religions. This pluralism is also reflected in the diverse Karo community in embracing religions such as Christian, Catholic, Islam and ancestral religions. Many religions are believed by Karo community, but the community's stigma still places that Karo community are Protestant Christians. Behind this stigma, there is a community of society whose entire population is Muslim. The villages are Tiga Beringin Village and Simpang Pergendangan Village, Tiga Binanga Sub-district. However, how is the relationship between the community groups well established and why there has never been a problem by the majority Christian population? This article will answer the things mentioned above which tell how the relationship between the community is harmoniously established and conflicts never occur.
\end{abstract}

Keywords

Christian, Islam local

wisdom

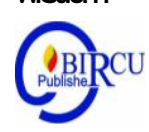

\section{Introduction}

Local wisdom in the diversity of religions in Karo is very interesting to study through the traces of the history of Islamic enclave settlements in Karo. The study will be more interesting and relevant especially when ethnicity, religion, and race are often used as an issue to gain power along with political euphoria and reform. This study focuses on the integration between Christians and Muslims in Karo spesifically in Tiga Beringin Villages and Simpang Pergendangen Villages, which aims to develop a multicultural society in Indonesia. Through this paper the authors try to show local wisdom in caring for diversity that lives together, giving and receiving the elements of integrative culture that is still ongoing nowadays. This paper is also expected to provide multiculturalism learning for the Indonesian society, by making historical facts and historical traces.

\section{Research Method}

Primary and secondary data collection techniques are carried out through direct observation or survey to the object of research (Tiga Beringin Village and Simpang Pergendangen Village) and looking for supporting data to libraries and institutions that are considered to be a source of data in research. For this paper, data search or new source is carried out in the National Archives of Republic of Indonesia and the National Library of Republic of Indonesia. The method of data analysis uses the historical analysis which aims to study and explore facts or experiences and past developments by trying to draw conclusions and try to make interpretations data from the event. 
The main data includes data relating to the diversity of local wisdom and religions in Karo. This data collection is done to obtain documents, archives, maps, reports, and so on as reference material. In addition to written and printed sources, in writing this paper also uses oral sources that is interviewing several informants who are considered to have an understanding of religionss diversity, while also interviewing local residents.

\section{Discussion}

\subsection{Custom as Harmonious Adhesives}

Daliken Si Telu or Rakut Si telu originates from Karo language, Daliken means stone stove for cooking while Si telu is three. So Daliken Si Telu means three stone stoves. The three stone stoves are used when they want to cook to form a triangle that has space on three sides whose position must be balanced and harmonious, from that side then put wood as fuel. In general, Karo community used to use stone stoves to cook food and use wood as fuel.

The three stoves serve as support poles for cooking based on how to cook, then Karo community understand what is called Daliken Si Telu. The stoves or supporting poles in Daliken Si Telu arrangement are: Sembuyak / Senina / Sukut, Kalimbubu, and Anak Beru. Daliken Si Telu kinship system is used both in traditional events, weddings, entering new homes, misfortune and including in solving social problems in Karo community such as land disputes, accidents and so forth. Daliken Si Telu is often also called Ralut Sitelu, which means three binds that reinforce each other, complement each other and must not be separated from each other.

Daliken Sitelu or Rakut Sitelu is the soul of Karo tribe, determining the status and role in family and community life. The status and role will apply wherever they are in both custom and daily life. However, the appointment of his position changes, depending on the situation where he is so that an Ethnic Karo, his adult camp will have all three statuses and roles. They also have to carry out their responsibilities according to their status and role without connecting to religion, position, rank, wealth and others ${ }^{1}$.

In the summary of Daliken Si telu, the position of Sembuyak, Kalimbubu and Anak Beru is only valid during the traditional ceremonies and celebration, families or clan groups that are positioned as Kalimbubu in certain traditional ways can also become Anak Beru or sukut in traditional ceremonies in other places. Kalimbubu is the master who must be served, while Anak Beru is a worker or servant for Kalimbubu. At a wedding ceremony, for example, Kalimbubu is a group of brothers or fathers on the wife who has a desire and her child is a party who wants to marry a sister from someone who has a traditional celebration or celebration. Sukut (sembuyak) parties who want to carry out certain ceremonies then they first conduct consultations assisted by Senina. Senina not only plays a role in helping consultations but also as a mediator that connects between Kalimbubu and Anak Beru related celebration or ceremony to be held. Therefore Senina must be chosen based on mutual family agreement because she is also responsible for the continuity of the event. Preferably a person who has kinship and emotional closeness so that he understands the situation and condition of the family of Sukut or from families who have intentions ${ }^{2}$.

\footnotetext{
${ }^{1}$ M. Abduh Lubis, "Budaya dan Solidaritas dakam Kerukunan Umat Beragama di Tanah Karo", Sosiologi Agama: Jurnal Ilmiah Sosiologi Agama dan Perubahan Sosial, Vol II, No. 2, July-December 2017, pp. 245246.

2 Tridah Bangun, Manusia Batak Karo, Jakarta: Inti Idayu Press, 1986, p. 104.
} 
Rakut Si Telu has been practiced continuously since the days of the previous king, even though he is a nation of kings if his position in traditional ceremonies is the son of a servant (worker and servant) then he must take care of all the traditional ceremonies, both from deliberations (traditional meetings), provision completeness of the event, consumption until cleaning after the completion of the custom event. Even though the young bear's position as official, this does not change the situation. For Karo ethnicity the term "la beradat" (not have custom) is very embarrassing. Telu Si Rakut continues to be carried out from generation to generation until now.

Every Karo community does this based on family ties and mutual awareness of customary rules, with Rakut Si Telu, each Karo community from different family groups and clans will meet and interact actively in traditional ceremonies, even if someone has a high government position when he and his family group occupy the position as the new bear in traditional ceremonies so he still has to work to serve his Kalimbubu even though Kalimbubu is a farmer and not a state official. This is because Kalimbubu is also considered a "Dibata Ni idah" (visible representative of God) so it must be respected and upheld within reasonable limits and not excessive. Respect is done starting from a special seat covered with white pandanus mats, a very polite way of speaking should not be careless, serving food and drinks preferred (not to be lacking. There is an assumption that if someone hurts his heart, he will not get luck. There is the term "melus sinaun-sinuan" which means the results of the first time or work will not get good results. When someone asks who is right wrong, then a person must apologize first, Kalimbubu must also respond to the attitude of the apology properly. This is what shows the harmony of structure in the community ${ }^{3}$.

\subsection{Religious Tolerance of Communities in Tiga Beringin Village and Simpang Pergendangen Village}

Tiga Beringin Village and Simpang Pergendangen Village are one proof of the high attitude of tolerance and wisdom in Karo community, especially in Tiga Binanga. In both villages, the population has been Muslim for generations. In Karo community, the value of land is quite large / valuable because it is related to economic life (agriculture). However, there is a wisdom for non-Muslim communities to release to their families who are Muslim because of the awareness that the basis is purely a Muslim. Although the basic Three Binanga majority are Christians. But there has never been a problem regarding land related to religion.

Likewise in the case of marriage, when there is a desire or arranged marriage from a society or relatives of different religions. When it was mentioned that one of the brides-to-be came from Tiga Beringin Village or Simpang Pergendangen Village, the community would immediately understand that the marriage would take place in Islamic terms. That does not mean blaming adherents of non-Muslim religions are not devout adherents. However, as if there is readiness and acceptance of Islam. If the family does not approve of religious differences in marriage, then they will advise or prohibit good matchmaking.

In Tiga Binanga, there is a location called a place of respect for the "nini pagar" which is a respected spirit / ancestor, especially Pemena followers. When people who still respect the fence hold a ritual at the location, such as asking for rain or worshiping, people in Tiga Beringin still attend. However, they were not involved in the ritual. Their presence is only as

\footnotetext{
${ }^{3}$ Roberto Bangun, Mengenal Orang Karo, Jakarta: Yayasan Pendidikan Bangun, 1989, p. 27.

${ }^{4}$ Nini pagar is a place of worship or a place of worship for Karo community who still embrace traditional religious beliefs that is "Pemena".
} 
a tolerance towards their relatives who still carry out the ritual. They only present and witness as a sense of brotherhood to their relatives.

When the happy or sad customary events, even though their relatives are non-Muslim, the people of Tiga Beringin Village and Simpang Pergendangen Village according to their status and role are also undergoing, sometimes even as a newborn child who must hold the main control in customary community discussion. Then they will carry out this role with full responsibility. There is no distinguishing attitude even though faithfully adheres to a different religion.

In Tiga Binanga Sub-district there is a tradition called merdang merdem (year work). Previously this event was related to a celebration of thanksgiving for the harvest as well as a family gathering event, relatives gather, party, eat together. Usually a new baby from outside the village will come to help his Kalimbu prepare for consumption. Likewise Kalimbu will come as an expression of his love for his newborn son who is celebrating the year work. The people of Tiga Beringin Village and Simpang Pergendangen Village did not celebrate this annual party. They only celebrate Eid al-Fitr. However, people from these two villages will visit other villages in Tiga Binanga Sub-district. If their position is new, they will arrive early. Usually the day before the peak day preparing food (cooking and serving) guests / relatives who come to the house of his relatives. Similarly, if its position as sukut (sembuyak) and kalimbubu. They were present as a sense of participating in the celebration.

The family (host) also shows tolerance towards Muslim relatives through the food served is halal. Starting from the preparation process (slaughter of cooked animals), cooking and presentation are all halal. Another tolerance is when the fasting month (Ramadhan), then people who are not Muslim will avoid to carry out a traditional party. Likewise in serving food at traditional events (joy and sorrow) in Tiga Binanga area very rarely provided food that is not halal. This is an effort to appreciate Muslim relatives.

In addition to the explanation above, there are also other forms of tolerance, namely when the community in both villages perform worship (prayer time), so when there are local residents who are holding events such as music keyboards and others, then fully aware of the volume will be reduced or take a short break waiting for time prayer is over. In addition, if one of the relatives is Muslim, and when the prayer time arrives, the non-Muslim family must remind and provide a prayer room with a white pandanus mat as a prayer mat. In Tiga Beringin village there is a Sijarul Huda Islamic school.

The Islamic school is located outside a village that is bordered by a population that is predominantly Christian. But there has never been a problem between the children who attend this place and the children outside it. They are good friends and harmonious. Parents have never taught these children to religious differences. It is precisely in the equation that is relatives (family). The children stressed that they are family with the words of their relatives such as senina, impal and others.

Both villages where the community are $100 \%$ Muslim, but there have never been complaints or harassment from the surrounding community who are non-Muslim. Karo community is known as an agrarian society, so assessing land is a very valuable economically and also prestige. But for this area if by chance there is land owned by non-Muslims that might be obtained from ancestral heritage, they will willingly let go so that the village is maintained as a Muslim settlement, despite the relinquishment of the rights through compensation or land exchange. In these two villages there are also the newcomers Muslim communities who are not originally Karo ethnic. Their presence is related to the spread of religions such as religious teachers and Islamic religious teachers, from marriages and so 
forth. But these newcomers can be accepted by the whole community and even the newcomers are given Karo clan as a form of appreciation and kinship.

\section{Conclusion}

Culture in the community occupies a very important role in the life of Karo community in Tiga Beringin Village and Simpang Pergendangen Village, Culture becomes a unifier as well as a guardian of the religious differences of the community, and the clan system inherited from ancestors from generation to generation is still maintained nowadays. Rakut $\mathrm{Si}$ Telu for Karo community in Tiga Beringin Village and Simpang Pergendangen Village has a great significance in reducing social problems and sentiments that trigger religious conflicts, the kinship system in Si Telu Rakut forms the solidarity of a community that synergizes with each other, respects each other and is able to move mutual cooperation, on the basis of emotional attachment between one another in the family home. Community solidarity in the culture forms a harmonious social space without having to contradict religious differences. The people in these two villages, although religiously obedient in religious life since hereditary, they are also able to maintain a very good relationship with the surrounding community in Tiga Binanga. In daily relationships are well established, as well as in traditional events, they do not connect different religions to carry out the status of their roles according to the Rakut Sitelu.

\section{Acknowledgment}

This article couldn't have been possible thanks to funding of "Penelitian TALENTA USU skema Penelitian Dasar" with the contract number 4167/UN5.1.R/PPM/2009 on 01 April 2019. We also thanks to Lembaga Penelitan USU which has accommodated this research. Besides that, we also thanks to Arsip Nasional Republik Indonesia because the sources of this article are widely available there.

\section{References}

Bangun, Roberto, 1989, Mengenal Orang Karo, Jakarta: Yayasan Pendidikan Bangun.

Bangun, Tridah, 1986, Manusia Batak Karo, Jakarta: Inti Idayu Press.

Brahmaputro, 1981, Karo Dari Zaman ke Zaman, Jilid I, Medan: Ulih Saber.

Bungin, H. M. Burhan, 2011, Penelitian Kualitatif, Jakarta: Prenada Media Group.

Ginting, Junita Setiana, 2012, Perubahan Sosial Budaya Merdang Merdem sebagai Tradisi pada Masyarakat Karo, Medan: Bartong Jaya.

Kasiram, H. Moh., 2010, Metodologi Penelitian Kualitatif-Kuantitaif, Malang: UIN Maliki Press.

Koentjaraningrat, 1982, Masyarakat dan Kebudayaan Indonesia, Jakarta: Grafiti Press.

Loeb, Edwin M., 2013, Sumatera: Sejarah dan Masyarakatnya, Yogyakarta: Ombak.

Lubis, M. Abduh, "Budaya dan Solidaritas dakam Kerukunan Umat Beragama di Tanah Karo", Sosiologi Agama: Jurnal Ilmiah Sosiologi Agama dan Perubahan Sosial, Vol II, No. 2, Juli-Desember 2017.

Moleong, Lexy J., 1999, Metodologi Penelitian Kualitatif, Bandung: PT. Remaja Rosdakarya.

Neumann, J. H., 2018, Sejarah Batak Karo Sebuah Sumbangan, Yogyakarta: Ombak. 
Perret, Daniel, 2010, Kolonialisme dan Etnisitas: Batak dan Melayu di Sumatera Timur Laut, Jakarta: KPG, EFEO, Forum Jakarta-Paris dan Puslit Arkenas.

Poerwandari, Kristi, 2005, Pendekatan Kualitatif dalam Penelitian Perilaku Manusia, Depok: LPSP3 FP UI.

Tamboen, P., 1952, Adat Istiadat Karo, Jakarta: Balai Pustaka. 